\title{
Pengelolaan Kelas Dipandang dari Perspektif Psikologi
}

\author{
Irnes Jakli Sy \\ Mahasiswa S3 Ilmu Pendidikan Universitas Negeri Padang \\ E-mail:irnes_jakli@yahoo.co.id
}

\begin{abstract}
This paper focuses on the problem of the management class. The views of the management ofclass had only understood as the ability piñata, control and regulate the class, so thatwell-organized classes and fun. Though not so. Management of the class was alsorelated to psychological aspects, administrative and paedagogis.In this paper the author tries to describe what are the components of classroom management, in addition tophysical aspects. So it can be understood that classroom management is a psychic and physical activityby teachers in designing the governance of the class in terms of psychology, administration and paedagogis.
\end{abstract}

Keywords — psychology, administration and paedagogis.

\section{PENDAHULUAN}

Pengelolaan kelas adalah keterampilan guru untuk menciptakan dan memelihara kondisi belajar yang optimal dan mengembalikannya bila terjadi gangguan dalam proses belajar mengajar. Suatu kondisi yang optimal dapat tercapai jika guru mampu siswa dan sarana pengajaran serta mengedalikannya dalam suasana yang menyenangkan untuk mencapai tujuan pengajaran. Pengelolaan kelas yang efektif merupakan persyaratan mutlak bagi terjadinya proses belajar mengajar. Pentingnya suatu pengelolaan kelas yang baik agar sehingga tercapainya proses belajar mengajar yang berdampak baik terhadap pencapaian prestasi belajar mengajar siswa atau anak didik.

Sebagai tenaga profesional, seorang guru maupun dosen dituntut mampu mengelola kelas dengan baik. Dimana keterampilan itu menciptakan dan mempertahankan kondisi belajar yang optimal bagi tercapainya tujuan pengajaran. Menurut Amatembun (dalam Supriyanto, 1991) "Pengelolaan kelas adalah upaya yang dilakukan oleh guru dalam menciptakan dan mempertahankan serta mengembang tumbuhkan motivasi belajar untuk mencapai tujuan yang telah di tetapkan". Sedangkan menurut Usman (2003)
"Pengelolaan kelas yang efektif merupakan prasyarat mutlak bagi terjadinya proses belajar mengajar yang efektif". Pengelolaan dipandang sebagai salah satu aspek penyelenggaraan sistem pembelajaran yang mendasar, di antara sekian macam tugas guru di dalam kelas. Berbagai definisi tentang pengelolaan kelas yang dapat diterima oleh para ahli pendidikan, yaitu : Pengelolaan kelas didefinisikan sebagai: a) Perangkat kegiatan guru untuk mengembangkan tingkah laku peserta didik yang diinginkan dan mengurangkan tingkah laku yang tidak diinginkan. b) Seperangkat kegiatan guru untuk mengembangkan hubungan interpersonal yang baik dan iklim sosio emosional kelas yang positif. c) Seperangkat kegiatan guru untuk menumbuhkan dan mempertahankan organisasi kelas yang efektif.

Pengelolaan Kelas diterjemahkan secara singkat sebagai suatu proses penyelenggaraan atau pengurusan ruang dimana dilakukan kegiatan belajar mengajar, dan untuk lebih jelasnya berikut pengertian pengelolaan kelas yang dikemukakan oleh Usman, bahwa "pengelolaan kelas adalah keterampilan guru untuk menciptakan dan memelihara kondisi belajar yang optimal dan mengembalikannya bila terjadi gangguan dalam proses belajar mengajar". Sedangkan menurut Wina Sanjaya bahwa pengelolaan kelas adalah: 
Pengelolaan kelas merupakan keterampilan guru menciptakan dan memelihara kondisi belajar yang optimal dan mengembalikannya manakala terjadi hal-hal yang dapat mengganggu suasana pembelajaran.

Beberapa pengertian pengelolaan kelas yang telah dikemukakan oleh para ahli di atas, dapatlah memberi suatu gambaran serta pemahaman yang jelas bahwa pengelolaan kelas merupakan suatu usaha menyiapkan kondisi yang optimal agar proses atau kegiatan belajar mengajar dapat berlangsung secara lancar. Pengelolaan kelas merupakan masalah yang amat kompleks dan seorang guru menggunakannya untuk menciptakan dan mempertahankan kondisi kelas sedemikian rupa sehingga anak didik dapat mencapai tujuan pembelajaran yang ditetapkan secara efektif dan efisien.

Pandangan mengenai pengelolaan kelas sebagaimana telah dikemukakan di atas intinya memiliki karakteristik yang sama, yaitu bahwa pengelolaan kelas merupakan sebuah upaya yang real untuk mewujudkan suatu kondisi proses atau kegiatan belajar mengajar yang efektif. Dengan pengelolaan kelas yang baik diharapkan dapat mendukung tercapainya tujuan pembelajaran di mana proses tersebut memberikan pengaruh positif yang secara langsung menunjang terselenggaranya proses belajar mengajar di kelas.

Dari beberapa definisi di atas, masing-masing mempunyai asumsi yang berbeda-beda. Para ahli menggabungkan beberapa dimensi itu menjadi definisi yang bersifat pluralistik, yaitu bahwa pengelolaan kelas sebagai seperangkat kegiatan untuk mengembangkan tingkah laku peserta didik yang diinginkan, menghubungkan interpersonal dan iklim sosio emosional yang positif serta mengembangkan dan mempertahankan organisasi kelas yang efektif.

Berdasarkan uraian di atas, maka fungsi pengelolaan kelas sangat mendasar sekali karena kegiatan guru dalam mengelola kelas meliputi kegiatan mengelola tingkah laku peserta didik dalam kelas, menciptakan iklim sosio emosional dan mengelola proses kelompok, sehingga keberhasilan guru dalam menciptakan kondisi yang memungkinkan, indikatornya proses belajar mengajar berlangsung secara efektif. Inti kegiatan suatu sekolah atau kelas adalah proses belajar mengajar (PBM). Kualitas belajar peserta didik serta para lulusan banyak ditentukan oleh keberhasilan pelaksanaan PBM tersebut atau dengan kata lain banyak ditentukan oleh fungsi dan peran guru.

Berdasarkan beberapa definisi di atas bahwa efektivitas pengelolaan kelas adalah tingkat tercapainya tujuan dari pengelolaan kelas. Pengelolaan kelas didefinisikan sebagai serangkaian tindakan yang dilakukan guru dalam upaya menciptakan kondisi kelas agar proses belajar mengajar dapat berjalan sesuai dengan tujuannya. Tindakan-tindakan yang perlu dilakukan guru dalam menciptakan kondisi kelas adalah melakukan komunikasi dan hubungan interpersonal antara guru peserta didik secara timbal balik dan efektif, selain melakukan perencanaan atau persiapan mengajar.

\section{GURU SEBAGAI PENGELOLA KELAS}

Mengajar pada prinsipnya membimbing siswa dalam kegiatan belajar mengajar atau mengandung pengertian bahwa mengajar merupakan suatu usaha pengorganisasian lingkungan dalam hubungannya dengan anak didik dan bahan pengajar yang menimbulkan proses belajar (Uzer Usman, 1988:6). Dari kutipan di atas mengandung makna bahwa gurulah yang mengatur mengawasi dan mengelola kelas agar tercapainya proses belajar mengajar yang berarah kepada tujuantujuan pendidikan. Hal ini sejalan dengan yang dikatakan oleh Syarifudin Nurdin bahwa guru sebagai salah satu komponen dalam kegiatan belajar mengajar, memiliki posisi yang sangat menentukan keberhasilan pembelajaran karena fungsi utama guru ialah merancang, mengelola, melaksanakan dan mengevaluasi pembelajaran (Syarifudin Nurdin, 2002:1).

Di samping itu pula guru bertanggung jawab memelihara lingkungan fisik kelasnya agar senantiasa menyenangkan untuk belajar dan lingkungan yang baik adalah yang bersifat menantang dan merangsang siswa untuk belajar, memberikan rasa aman dan kepuasan dalam mencapai tujuannya (Uzer Usman, 1998:10). Keberhasilan guru menjadi suatu harapan orang tua. Sebagaimana dijelaskan Johnson,E.B (2007:226), mengatakan bahwa "orang tua murid tahu bahwa lingkungan sekolah sangat kuatmempengaruhi akan jadi seperti apa anaknya nanti, oleh karena itu orang tua berharap guru harus menciptakan lingkungan kelas yang mendukung dan member semangat kepada anak". 
Guru sebagai pengelola kelas merupakan orang yang mempunyai peranan yang strategis yaitu orang yang merencanakan kegiatan-kegiatan yang akan dilakukan di kelas, orang yang akan mengimplementasikan kegiatan yang direncanakan dengan subjek dan objek peserta didik, orang menentukan dan mengambil keputusan dengan strategi yang akan digunakan dengan berbagai kegiatan di kelas, dan guru pula yang akan menentukan alternatif solusi untuk mengatasi hambatan dan tantangan yang muncul; maka dengan beberapa pendekatan-pendekatan yang dikemukakan, akan sangat membantu guru dalam melaksanakan tugas pekerjaannya.

Guru dalam melakukan tugas mengajar di suatu kelas, perlu merencanakan dan menentukan pengelolaan kelas yang bagaimana yang perlu dilakukan dengan memperhatikan kondisi kemampuan belajar peserta didik serta materi pelajaran yang akan diajarkan di kelas tersebut. Menyusun strategi untuk mengantisipasi apabila hambatan dan tantangan muncul agar proses belajar mengajar tetap dapat berjalan dan tujuan pembelajaran yang telah ditentukan dapat tercapai. Pengelolaan kelas akan menjadi sederhana untuk dilakukan apabila guru memiliki motivasi kerja yang tinggi, dan guru mengetahui bahwa gaya kepemimpinan situasional akan sangat bermanfaat bagi guru dalam melakukan tugas mengajarnya.

Dengan demikian pengelolaan kelas tidak dapat terlepas dari motivasi kerja guru, karena dengan motivasi kerja guru ini akan terlihat sejauh mana motif dan motivasi guru untuk melakukan pengelolaan kelas, sedangkan dengan gaya kepemimpinan guru yang tepat yang digunakan dalam pengelolaan kelas akan mengoptimalkan dan memaksimalkan keberhasilan pengelolaan kelas tersebut.

\section{TEORI MOTIVASI DALAM PENGELOLAAN KELAS}

Abraham H. Maslow dengan teori motivasi-nya mengemukakan ada lima tingkatan kebutuhan manusia secara berjenjang : 1) phisik : sandang, pangan, dan papan; 2) rasa aman dan jaminan : tidak ada kekawatiran akan dikeluarkan dari tempat kerja sewaktu-waktu; 3) kasih sayang dan kebersamaan; 4) penghargaan dan pengakuan; dan 5) aktualisasi diri. (David \& Newstorm, 1990:6871; Hersey \& Blanchard, 1993:33-38; French, 1986:113-114). Dikatakan bahwa pada umumnya kebutuhan yang lebih tinggi tingkatannya akan muncul setelah kebutuhan pada tingkatan sebelumnya terpenuhi/ terpuaskan. David Mc. Clelland (French, 1986:115-116; Wexley, 1991:227-231) dengan Three $N$ yaitu : 1) needs for achievement; 2) needs for power; 3) needs for afiliation. Orang butuh berprestasi, kekuasaan dan afiliasi. Hasil penelitian David Mc. Clelland menunjukkan bahwa kebutuhan berprestasi merupakan kebutuhan manusia yang nyata, yang dapat dibedakan dengan yang lain, dan memerlukan motivasi yang cukup tinggi. Frederik Herzberg (French, 1986:116-117; Hersey \& Blanchard, 1993:69-74) menjelaskan bahwa ada faktor motivator yang bersifat langsung dan ada faktor hygiene yang bersifat tidak langsung, yang berkaitan dengan motivasi (dalam Andyarto Surjana, 2004:73).

Faktor-faktor motivator: prestasi, pengakuan, tanggungjawab. Faktor-faktor hygiene: kebijakan organisasi, pengawasan, gaji, hubungan interpersonal, dan kondisi kerja. Hersey \& Blanchard (1986, 69-74) kaitannya dengan kerangka motivasi dan tujuan menjelaskan keterkaitan teori Maslow dengan Herzberg. Maslow mengidentifikasi kebutuhan atau motif yang ada pada seseorang dalam melakukan kegiatan, sedangkan Herzberg menitik beratkan pada kepuasan kegiatan (prestasi) yang akan memotivasi seseorang dalam melakukan kegiatannya. Kebutuhan penghargaan, pengakuan, aktualisasi diri pada hiarki Maslow merupakan faktor motivator-nya Herzberg, sedangkan kebutuhan fisiologi, rasa aman dan jaminan, cinta kasih dan kerbersamaan, serta sebagian kebutuhan penghargaan dan pengakuan pada hiarki Maslow, identik dengan faktor hygiene-nya Herzberg (dalam Andyarto Surjana, 2004:73).

Berdasarkan pembahasan di atas yang berkaitan dengan motivasi, dapat disimpulkan definisi motivasi adalah dorongan yang muncul dalam diri seseorang untuk melakukan serangkaian kegiatan yang berkaitan dengan tujuan yang ingin dicapai. Dorongan ini muncul dikarenakan adanya kebutuhan. Kebutuhan dan tingkatan kebutuhan yang dikemukakan oleh Abraham H. Maslow, David Mc. Clelland yaitu kebutuhan untuk berprestasi, faktor internal ataupun faktor eksternal.

Keberhasilan pengelolaan kelas bergantung pada motivasi guru, artinya guru yang memiliki motivasi yang tinggi akan dapat mengelola kelas 
dengan baik dan tepat. Mengelola kelas itu sendiri bukanlah tujuan utama dari setiap guru, akan tetapi apabila guru dapat mengelola kelas dengan baik, maka kegiatan belajar mengajar-nya akan berjalan baik dan peserta didik-peserta didiknya akan berprestasi tinggi. Mengelola kelas merupakan sarana/alat untuk mencapai tujuan yang ingin dicapai dari kegiatan belajar mengajar. Tujuan guru pada dasarnya adalah bagaimana guru dapat mentransfer materi pelajaran dengan baik, sehingga peserta didik dapat mengerti dan menerima materi pelajaran yang diajarkan

Mencermati teori kebutuhan Abraham Maslow, teori kebutuhan berprestasi David Mc. Clelland, teori ekspektansi Victor H. Vroom, maka motivasi guru menjadi dasar pertama untuk keberhasilan guru dalam mengelola kelas. Guru yang puas dengan apa yang diperoleh atau apa yang dapat dicapai dari hasil dan lingkungan kerja akan dapat berperan banyak dibandingkan dengan guru yang memiliki motivasi rendah (dalam Andyarto Surjana, 2004:73).

Disadari atau tidak, motivasi kerja guru akan mempengaruhi perilaku guru dalam melakukan tugas pekerjaannya. Guru yang pertama-tama memikirkan mengenai penghasilan/gaji akan memandang pekerjaannya sebagai sarana untuk mendapatkan uang, dan sekolah merupakan organisasi yang menjamin kesejahteraan guru. Guru akan cenderung agar sekolah menerima peserta didik baru dengan memperhatikan kemampuan ekonomi peserta didik/orang tua peserta didik. Guru akan berupaya untuk memberikan pelajaran tambahan sebanyak mungkin pada peserta didik agar mendapatkan tambahan honor sebagaimana diharapkan. Guru juga akan mengajar di banyak sekolah agar mendapat penghasilan tambahan. Akibat perilaku guru seperti itu, guru tidak akan sempat mempersiapkan pelajarannya dengan baik atau memeriksa tugas peserta didik satu per satu; guru hanya akan mengajar dengan metode mengajar yang mudah dilakukan baginya tanpa memperhatikan apakah peserta didik-peserta didiknya dapat mengerti materi pelajaran yang diajarkannya

Sebaliknya guru yang menaruh perhatian pada perkembangan peserta didik, akan berupaya menyumbangkan segala kemampuannya untuk kepentingan peserta didik. Guru berupaya membantu peserta didik yang mempunyai kemampuan belajar yang rendah. Guru akan menggunakan berbagai metoda mengajar agar peserta didik dapat mengerti materi pelajaran yang diajarkannya. Guru tersebut akan mempunyai kreativitas yang tinggi; mau mengorbankan waktunya agar peserta didik bisa berprestasi. Guru akan merasa puas apabila peserta didik berhasil dengan baik. Kedua perilaku guru yang digambarkan di atas tidak terlepas dari motivasi yang dimiliki guru. Guru yang satu mempunyai motivasi hanya sekedar untuk memenuhi kebutuhan hidup, sedangkan guru yang lain mempunyai motivasi yang tinggi, bukan untuk kepentingan diri guru itu sendiri, melainkan untuk kepentingan peserta didik, untuk kepentingan proses belajar mengajar yang dilakukannya agar peserta didik dapat menerima materi pelajaran yang diajarkannya, dapat mengembangkan potensi dirinya, dapat mempunyai wawasan yang luas dan berprestasi tinggi.

Guru yang memiliki motivasi yang tinggi dan tidak hanya untuk kepentingan dirinya, akan dapat melakukan pengelolaan kelas dengan tepat. Guru tersebut akan menaruh perhatian bagi peserta didik dan kelasnya. Guru akan melakukan yang terbaik bagi peserta didik. Dalam mentransfer materi pelajaran pada peserta didik, guru akan mempelajari dan mengatur kelas sedemikian rupa sehingga dapat digunakan untuk melaksanakan proses belajar mengajar dengan baik. Guru akan mencermati kemampuan para peserta didik satu per satu, sehingga guru mengetahui kemampuan peserta didik pada tingkatan rendah, sedang atau tinggi.

Dengan demikian guru akan menentukan peserta didik-peserta didik yang mana, yang perlu mendapat bimbingan yang banyak; guru dapat menentukan metoda mengajar atau media pembelajaran yang harus digunakan. Guru akan menentukan berapa banyak tugas yang perlu diberikan. Hubungan yang bagaimana yang perlu dilakukan guru dengan peserta didik, agar kesulitan belajar peserta didik dapat teratasi; motivasi belajar peserta didik terus meningkat.

Secara sederhana dapat disimpulkan bahwa motivasi kerja guru ada hubungan dengan efektivitas pengelolaan kelas. Makin tinggi motivasi kerja guru, makin tinggi efektivitas pengelolaan kelas yang dapat dicapai. Demikian pula motivasi kerja guru ada hubungannya dengan gaya kepemimpinan guru dalam arti guru yang 
memiliki motivasi kerja tinggi, akan berupaya untuk melakukan berbagai strategi untuk keberhasilan PBM-nya termasuk untuk menggunakan gaya kepemimpinan yang tepat (dalam Andyarto Surjana, 2004:73).

Peserta didik sebagai subjek pendidikan dalam PBM, dapat dipastikan mempunyai kemampuan dan karakter yang berbeda-beda, karena mempunyai tingkat kematangan yang berbeda. Gaya Kepemimpinan didefinisikan sebagai pola tindakan yang dilakukan guru, yang disesuaikan dengan kebutuhan berdasarkan kemampuan peserta didik. Pola tindakan yang perlu dimiliki guru adalah pola tindak yang berorientasi pada tugas, dan yang berorientasi pada hubungan.

Pola tindakan yang berorientasi pada tugas bertujuan untuk membantu peserta didik terutama yang mempunyai kemampuan melakukan tugas rendah, agar dapat menyelesaikan tugas dengan benar. Pola tindak yang berorientasi pada hubungan bertujuan untuk mengkondisikan situasi kelas/belajar mengajar (memotivasi atau menstimulasi atau mempengaruhi), agar tugas/kegiatan guru dan peserta didik dapat dilakukan dengan tepat. (dalam Andyarto Surjana, 2004:73).

\section{TUJUAN PENGELOLAAN KELAS}

Tujuan pengelolaan kelas lebih berorientasi pada mengkondisikan dan memanipulasi suasana belajar, sehingga menjadi suasana yang menyenangkan dan efektif dalam pencapaian tujuan. Menurut Usman pengelolaan kelas mempunyai dua tujuan yaitu tujuan umum dan tujuan khusus. Tujuan umum pengelolaan kelas adalah menyediakan dan menggunakan fasilitas belajar untuk bermacam-macam kegiatan belajar mengajar agar mencapai hasil yang baik. Sedangkan tujuan khususnya adalah mengembangkan kemampuan peserta didik dalam menggunakan alat-alat belajar, menyediakan kondisi-kondisi yang memungkinkan peserta didik bekerja dan belajar, serta membantu peserta didik untuk memperoleh hasil yang diharapkan.

Tujuan pengelolaan kelas pada hakikatnya telah terkandung pada tujuan pendidikan dan secara umum tujuan pengelolaan kelas adalah penyediaan fasilitas bagi bermacam - macam kegiatan belajar peserta didik sehingga subjek didik terhindar dari permasalahan mengganggu seperti peserta didik mengantuk, enggan mengerjakan tugas, terlambat masuk kelas, mengajukan pertanyaan aneh dan lain sebagainya.

Menurut Ahmad (1995) bahwa tujuan pengelolaan kelas adalah sebagai berikut:

1) Mewujudkan situasi dan kondisi kelas, baik sebagai lingkungan belajar maupun sebagai kelompok belajar yang memungkinkan peserta didik untuk mengembangkan kemampuan semaksimal mungkin.

2) Menghilangkan berbagai hambatan yang dapat menghalangi terwujudnya interaksi belajar mengajar.

3) Menyediakan dan mengatur fasilitas serta perabot belajar yang mendukung dan memungkinkan peserta didik belajar sesuai dengan lingkungan sosial, emosional, dan intelektual peserta didik dalam kelas.

4) Membina dan membimbing sesuai dengan latar belakang sosial, ekonomi, budaya serta sifat-sifat individunya.

Tujuan pengelolaan kelas menurut Sudirman (dalam Djamarah 2006) pada hakikatnya terkandung dalam tujuan pendidikan. Tujuan pengelolaan kelas adalah penyediaan fasilitas bagi macam-macam kegiatan belajar peserta didik dalam lingkungan sosial, emosional, dan intelektual dalam kelas. Fasilitas yang disediakan itu memungkinkan peserta didik belajar dan bekerja. Terciptanya suasana sosial yang memberikan kepuasan, suasana disiplin, perkembangan intelektual, emosional, dan sikap serta apresiasi pada peserta didik. Sedangkan Arikunto (dalam Djamarah 2006) berpendapat bahwa tujuan pengelolaan kelas adalah agar setiap anak di kelas dapat bekerja dengan tertib sehingga segera tercapai tujuan pengajaran secara efektif dan efisian. Menurutnya sebagai sebuah indikator dari sebuah kelas yang tertib adalah apabila:

1) Setiap peserta didik terus bekerja, tidak macet artinya tidak ada anak yang terhenti karena tidak tahu ada tugas yang harus dilakukan atau tidak dapat melakukan tugas yang diberikan padanya.

2) Setiap peserta didik terus melakukan pekerjaan tanpa membuang waktu artinya setiap peserta didik akan bekerja secepatnya supaya lekas menyelesaikan tugas yang diberikan padanya.

Dengan demikian dapat disimpulkan bahwa tujuan pengelolaan kelas adalah menyediakan, menciptakan dan memelihara kondisi yang optimal di dalam kelas sehingga peserta didik dapat belajar dan bekerja dengan baik. Selain itu juga guru dapat mengembangkan dan menggunakan alat bantu belajar yang digunakan dalam proses belajar mengajar sehingga dapat membantu peserta didik dalam mencapai hasil belajar yang diinginkan. 
Tujuan pengelolaan kelas yaitu menciptakan dan menjaga kondisi kelas agar PBM dapat berlangsung dengan baik sesuai dengan sasarannya. Artinya upaya yang dilakukan oleh guru, agar peserta didik-peserta didik yang kemampuannya tidak semuanya sama, dapat mengikuti dan menguasai materi pelajaran yang diajarkan guru. Kepemimpinan situasional dengan gaya kepemimpinan situasionalnya yang dimiliki guru merupakan solusi untuk keberhasilan pengelolaan kelas yang efektif. Guru akan selalu mempelajari kondisi peserta didik di kelas tempat guru tersebut mengajar, dan menentukan apa yang harus dilakukan oleh guru, sehingga kegiatan belajar mengajar dapat berjalan dengan baik dan tujuan pengajaran tercapai. Menurut Hersey \& Blanchard, perilaku tugas dan perilaku hubungan akan mengoptimalkan kegiatan belajar mengajar di kelas tersebut. Berdasarkan pada ketiga paparan di atas dapat disimpulkan bahwa pengelolaan kelas yang efektif dapat dicapai dengan motivasi kerja guru yang tinggi, dan gaya kepemimpinan situasional yang dianut oleh guru.

Pada dasarnya kegiatan guru dikelas mencakup dua aspek utama, yaitu masalah pembelajaran dan masalah pengelolaan kelas. Berdasarkan definisi didepan, maka seorang guru akan berhadapan masalah individu dan masalah kelompok. Untuk dapat menyelesaikan masalah pengelolaan kelas yang efektif, maka guru harus mampu: mengidetifikasikan masalah yang bersifat individu dan kelompok, memahami berbagai pendekatan untuk menyelesaikan suatu permasalahan dan memilih pendekatan yang paling tepat untuk menyelesaikan masalah tersebut.

a) Masalah Individu Asumsi yang mendasari masalah individu adalah bahwa tingkah laku manusia itu mengarah pada pencapaian suatu tujuan. Setiap individu memiliki kebutuhan dasar untuk memiliki atau merasa dirinya berguna dan dibutuhkan. Jika individu gagal dalam mendapatkannya, maka ia akan bertingkah laku secara berurutan dimulai dari yang paling ringan sampai denga yang paling berat.

b) Masalah Kelompok Terdapat tujuh masalah kelompok yang berkaitan dngan pengelolaan kelas, yaitu: (1) Hubungan tidak harmonis, (2) Kekurangmampuan mengikuti peraturan kelompok, (3) Reaksi negatif terhadap sesama anggota kelompok, (4) Penerimaan kelompok atas tingkah laku yang menyimpang, (5) Penyimpangan anggota kelompok dari ketentuan yang ditetapkan, (6) Tidak memiliki teman, tidak mau bekerja, atau bertingkah laku yang negatif, (7) Ketidakmampuan menyesuaikan diri terhadap perubahan lingkungan

\section{PRINSIP PRINSIP PENGELOLAAN KELAS}

"Secara umum faktor yang mempengaruhi pengelolaan kelas dibagi menjadi dua golongan yaitu, faktor intern dan faktor ekstern peserta didik." (Djamarah 2006). Faktor intern peserta didik berhubungan dengan masalah emosi, pikiran, dan perilaku. Kepribadian peserta didik denga ciriciri khasnya masing-masing menyebabkan peserta didik berbeda dari peserta didik lainnya sacara individual. Perbedaan sacara individual ini dilihat dari segi aspek yaitu perbedaan biologis, intelektual, dan psikologis. Faktor ekstern peserta didik terkait dengan masalah suasana lingkungan belajar, penempatan peserta didik, pengelompokan peserta didik, jumlah peserta didik, dan sebagainya. Masalah jumlah peserta didik di kelas akan mewarnai dinamika kelas. Semakin banyak jumlah peserta didik di kelas, misalnya dua puluh orang ke atas akan cenderung lebih mudah terjadi konflik. Sebaliknya semakin sedikit jumlah peserta didik di kelas cenderung lebih kecil terjadi konflik.

\section{KOMPONEN-KOMPONEN KETERAMPILAN PENGELOLAAN KELAS}

Komponen komponen keterampilan pengelolaan kelas ini pada umumnya dibagi menjadi dua bagian, yaitu keterampilan yang berhubungan dengan penciptaan dan pemeliharaan kondisi belajar yang optimal (bersifat preventif) dan keterampilan yang berhubungan dengan pengembangan kondisi belajar yang optimal (Mulyasa, 2005:91).

Banyak langkah yang perlu dipahami pendidik berkaitan penciptaan dan pemeliharaan iklim pembelajaran yang optimal. Hal ini meliputi:
a) Menunjukkan sikap tanggap dengan cara: memandang secara seksama, mendekati, memberikan pernyataan dan memberi reaksi terhadap gangguan di kelas.
b) Membagi perhatian secara visual dan verbal.
c) Memusatkan perhatian kelompok dengan cara menyiapkan peserta didik dalam pembeljaran.
d) Memberi petunjuk yang jelas.
e) Memberi teguran secara bijaksana.
f) Memberi penguatan ketika diperlukan.

Keterampilan yang berhubungan dengan penciptaan dan pemeliharaan kondisi belajar yang optimal terdiri dari: keterampilan sikap tanggap, 
membagi perhatian, pemusatan perhatian kelompok. Keterampilan suka tanggap ini dapat dilakukan dengan cara memandang secara seksama, gerakan mendekat, memberi pertanyaan, dan memberi reaksi terhadap gangguan dan kekacauan. Yang termasuk ke dalam keterampilan memberi perhatian adalah visual dan verbal. Tetapi memberi tanda, penghentian jawaban, pengarahan dan petunjuk yang jelas, penghentian penguatan, kelancaran dan percepatan, merupakan sub bagian dari keterampilan pemusatan perhatian kelompok.

Masalah modifikasi tingkah laku, pendekatan pemecahan masalah kelompok, dan menemukan serta memecahkan tingkah laku yang menimbulkan masalah, adalah tiga buah strategi yang termasuk ke dalam ruang lingkup keterampilan yang berhubungan dengan pengembangan kondisi belajar yang optimal

\section{KESIMPULAN}

Pengelolaan kelas adalah keterampilan guru untuk menciptakan dan memelihara kondisi belajar yang optimal dan mengembalikannya bila terjadi gangguan dalam proses belajar mengajar. Fungsi pengelolaan kelas sangat mendasar sekali karena kegiatan guru dalam mengelola kelas meliputi kegiatan mengelola tingkah laku peserta didik dalam kelas, menciptakan iklim sosio emosional dan mengelola proses kelompok, sehingga keberhasilan guru dalam menciptakan kondisi yang memungkinkan, indikatornya proses belajar mengajar berlangsung secara efektif.

Guru sebagai pengelola kelas merupakan orang yang mempunyai peranan yang strategis yaitu orang yang merencanakan kegiatan-kegiatan yang akan dilakukan di kelas, orang yang akan mengimplementasikan kegiatan yang direncanakan dengan subjek dan objek peserta didik, orang menentukan dan mengambil keputusan dengan strategi yang akan digunakan dengan berbagai kegiatan di kelas, dan guru pula yang akan menentukan alternatif solusi untuk mengatasi hambatan dan tantangan yang muncul; maka dengan beberapa pendekatan-pendekatan yang dikemukakan, akan sangat membantu guru dalam melaksanakan tugas pekerjaannya.

Dengan demikian pengelolaan kelas tidak dapat terlepas dari motivasi kerja guru, karena dengan motivasi kerja guru ini akan terlihat sejauhmana motif dan motivasi guru untuk melakukan pengelolaan kelas, sedangkan dengan gaya kepemimpinan guru.

\section{DAFTAR PUSTAKA}

[1] Bergenhahn,\& Olson H. Mattew. 2008. Theories of Learning (Teori Belajar) Edisi Ketujuh. Jakarta: kencana

[2] Cooper, James M. (1995). Classroom teaching Skills. Lexington : D.C. Heath and Company.

[3] Depdiknas. (1994). Kurikulum SMU petunjuk pelaksanaan administrasi pendidikan di sekolah. Jakarta : Dirjen Dikdasmen Dirdikmenun.

[4] Donelly, James H., Jr., Gibson, James L., and Ivancevich, John M. (1989). Management, principles and functions. Boston.

[5] Hendyat Soetopo. (2005). Pendidikan dan Pembelajaran, Teori, Permasalahan, dan Praktek. Malang: UMM Press

[6] Mulyasa. 2005. Menjasdi guru Pofesional. Bandung: Remaja Rosdakarya

[7] Mudyahardjo, Redja. 2008. Pengantar Pendidikan. Jakarta: Radja Grafindo Persada

[8] Sarwono, W. Sarlito. 2010. Psikologi Umum. Jakarta: Rajawali Pers

[9] Slavin, R.E. 2000. Educational Psychology: Theory and Practice. Sixth Edition. Boston: Allyn and Bacon

[10] Sunaryo. 2002. Psikologi Untuk Keperawatan. Jakarta: EGC.

[11] Suraysubrata, Sumadi. 2004. Psikologi Pendidikan. Jakarta: Raja Grafindo

[12] Usman, Moh. Uzer. (2003). Menjadi guru profesional. Bandung : Remaja Rosda Karya

[13] Wina Sanjaya. (2005). Pembelajaran dalam Implementasi Kurikulum Berbasis Kompetensi. Jakarta: Kencana Prenada Media Grup

[14] Purwanto, Ngalim. 2004. Psikologi Pendidikan. Bandung: Remaja Rosda Karya 